\title{
The US of America: Speech at the NAAS Conference in Tampere, 2007
}

\section{Gunlög Fur}

Växjö University

\begin{abstract}
Who is included and who is not in the family of "us" in United States history? Here this question is related to a concern with the formulation of aims for American Studies in Scandinavia and inspired this presentation at the NAAS conference in Tampere 2007. The "essentially contested concept" of who is an American is discussed in the context of Native American presence and absence in the grand narrative of the history of the US. Native American history has had little impact on the national narrative, but it is argued here that attention to it challenges the boundaries of the US in three dimensions - through expanding the chronology, the geographical limits, and by complicating the many layers of human presence in the landscape. Investigations of the relationship between Delaware Indians and colonists in early Pennsylvania, the Comanche empire in the Southwest, and the struggles over belonging in the upper Midwest constitute examples of exercises that stretch the boundaries of the historical field. This, it is argued, ought to be reflected in the scope of American Studies.
\end{abstract}

Keywords: US history-national narratives-Native American history-Delaware Indians-Comanche empire-inclusion

There is little doubt that there is an US built into the very foundation of any nation -in this case there is nothing exceptional with the US of A. This $u s$ differentiates between members of a nation and non-members, as well as between members within the nation, not uncommonly on the basis of gender and race. Again, there is nothing unique or original in stating that this also describes the experiences of people within and without the United States. More controversial is to argue that a violent distancing of gendered and racialized bodies were-and are-intrinsic to the formation of this US. 
This speech is a reflection on the formation of an US, as in the United States, from the perspective of a historian of Native America, and it is prompted by the sense of unease with which I have long contemplated the statutes of the Nordic Association for American Studies. What you get here is, therefore, my subjective argument for a change of focus and scope in American Studies.

The Articles state that the purpose of the organization "shall be to encourage the study of the United States, particularly in Denmark, Finland, Iceland, Norway, and Sweden."

Now, I am not a fool. I fully realize that this wording is in accordance with statutes for American Studies associations around the globe. I am also aware of other, separate associations for the study of Canada and other areas of the American continent. Yet, I find this wording problematic, as well as inappropriate. These are my reasons:

1. It is problematic in terms of limitations. I for one have primarily studied, written about, and presented papers at American Studies conferences on themes that do not fit into this description. My research in Native American history, and colonial encounters centers on a period prior to the founding of the United States of America. I am open to the suggestion that what I do and focus on should not be a part of American Studies defined in the present way, but so far I have not had any indications that this is the desire of the organization.

2. It limits the critical and comparative inquiry. I find it questionable to conceptualize "America" in a way that conforms with an understanding of American Studies that was promoted as a part of Cold War strategy, that accepts the imperial notion of the United States as synonymous with "America". In my opinion it is precisely such constructions that ought to be in focus for critical evaluation and study, not be accepted at face value.

3. Finally I believe that membership will not be helped with such a formulation. It is my observation from the Swedish academic and cultural perspective that there is great interest in seeking to understand and study "America" in relation to Sweden, Europe, and the rest of the world. Limiting it geographically to the political entity of the United States is not appropriate to the questions posed.

Joyce Chaplin, in her presidential address to the Organization of American Historians congress in 2002, bemoaned the lack of permeable borders between early American history and historical experience elsewhere. In spite of the growth of a field known as Atlantic history, traditional US history has remained much the same. She continued to say that "[1]ack of attention to legal studies of indigenous rights - the province mostly of Canadian and 
Australasian scholars-likewise precludes a truly transnational and comparative understanding of early America."1

Chaplin in the same article examines persistent US ideas about exceptionalism, and argues that "all versions of exceptionalism ignore how the colonies and the United States shared histories (including reprehensible histories) with other societies and peoples." She continues:

Ignorance of what is going on in parallel fields can easily generate an illusion of uniqueness where none exists; an overwhelming attention to how colonial history provides "background" for U.S. history can only reinforce that tendency, as it always has. ${ }^{2}$

A similar plotting could be done for slavery or for the Latino population now in the US. For neither study is the United States in itself as a temporal and political entity the most relevant delineation.

American, writes historian Eric Foner, "is what philosophers call an 'essentially contested concept' - one that by its very nature is subject to multiple and conflicting interpretations." ${ }^{3}$ He then cites J. Héctor St. John de Crèvecoeur's famous question: "What then is the American, the new man?", and his response: "a mixture of English, Scotch, Irish, French, Dutch, Germans, and Swedes .... He is either a European, or the descendant of a European."4 Crèvecoeur's contention illustrates what Foner identifies as two seemingly inpenetrable barriers to citizenship, barriers that simultaneously served to uphold the very meaning of citizenship, both of them hinging upon race: slavery and colonial expansion. Slavery, he argues, "helped to shape the identity, the sense of self, of all Americans, giving nationhood from the outset a powerful exclusionary dimension ... slavery rendered blacks all but invisible to those imagining the American community." And colonial expansion westward into the continent "created a sense, among white Americans, of land ownership as an entitlement of citizenship."

Fundamentally, I argue, it is these assumptions that underlay the present

1 Joyce E. Chaplin, "Expansion and Exceptionalism in Early American History," Journal of American History 89:4 (March 2003): 1432.

2 Ibid., 1433.

3 Eric Foner, Who Owns History? Rethinking the Past in a Changing World, New York: Hill and Wang, 2003 (2002), 151.

4 Foner, ibid., 153.

5 Foner, ibid., 152-153.

6 Foner, ibid., 156. 
formulation of boundaries encircling the field of American Studies. Slavery has, fortunately, been so discredited - mostly due to the valiant efforts of African Americans and allies to redefine notions of race and citizenshipthat the scholarship on African experiences in America at large have had a profound impact on the study of the US. Entrenched notions of colonial expansion have not been demolished in the same way, in spite of varied efforts. Why this is so is beyond the scope of this presentation, but perhaps it is because the idea of private ownership of land is a foundation without which the US would cease to be. Literary scholar Kate Shanley suggests that Native Americans "are a permanent 'present absence' in the U.S. colonial imagination, an 'absence' that reinforces at every turn the conviction that Native peoples are indeed vanishing and that the conquest of Native lands is justified." Others have pointed to the significance of contributions of literary imagination -in particular James Fenimore Cooper's. His depiction of the fictional characters Chingachgook and Uncas impressed generations of readers - and movie goers - immensely, but, as Jacquelyn Kirkpatrick notes in her book on Indians on the celluloid screen, "it is important to note that they are the last of their breed. These proto-American allegories were conveniently vanishing, leaving the land open for Euro-Americans to take their 'rightful' place."'

In any case, scholarship on Native American history has had much less impact on the study of the US than that of African American history. Chaplin foregrounds ethnohistory and the so-called new Indian history as "two of the most important developments in early American history," yet it has not led to "radical assessments of the Indian place in American history." She suggests two reasons, firstly that "the complexities of Native American societies elude many early Americanists," and secondly that "the critical edge of some of the new Indian history, which categorizes colonization and colonies as insidious and which sees the Revolution and the creation of the United States as tragic developments, has had a limited impact." Daniel Richter is even more forthright: "to call Western European Progress a tragedy for non-Western Europeans - as one must do when writing etic

7 quoted in Andrea Smith, Conquest. Sexual Violence and American Indian Genocide, Cambridge: Southend Press, 2005, 9.

8 Jacquelyn Kilpatrick, Celluloid Indians. Native Americans and Film, Lincoln: University of Nebraska Press, 1999, 3 .

9 Chaplin, "Expansion and Exceptionalism," 1447-1448. 
history - is to challenge white Americans' sense of who they are."10 James Merrell found in researching his book on the Catawba nation that previous scholarship had "presumed a barrier between Indians and everyone else in early America" which his readings of the sources did not support. He concluded that the question of this separation has come up so often "because the notion that Indians are somehow separate from the history of colonial America-indecd, of all Amcrica - is so common."11 Ned Blackhawk recently commented on the strains inherent in teaching Native American History and American History at University of Wisconsin, one of the most prestigious universities in the US:

Indian history appears increasingly critical to nearly all epochs of the nation's past, while in the classroom reconciling commonplace assumptions about America with the traumatic histories of the continent's indigenous peoples can be an exceedingly turbulent endeavor. ${ }^{12}$

Taking my cue from Blackhawk's recognition of the history of the continent and from the recent challenges to inclusionary/exclusionary practices through references to the "War on Terrorism" I want to argue that the international American Studies community has a strong responsibility, if not obligation, not to let these practices define the field of study. In the following I would like to expand the boundaries of American Studies by using examples from my field of research and teaching - Native American history. I will suggest three ways in which it challenges the construction of the US: horizontally, by expanding the time line; geographically, by moving the focus and balance point of American history; and geometrically, by expanding vertically.

10 Daniel K. Richter, "Whose Indian History?", The William and Mary Quarterly, 3rd ser, vol L:2 (April 1993), 389.

11 James H. Merrell, The Indians' New World. Catawbas and Their Neighbors from European Contact through the Era of Removal, Chapel Hill: University of North Carolina Press, 1989, vii.

12 Ned Blackhawk, "Recasting the Narrative of America: The Rewards and Challenges of Teaching American Indian History," Journal of American History 93:4 (March 2007), 1165. 


\section{Challenging chronology: Delawares in the peaceable kingdom}

In April of 1756 Pennsylvania governor Robert Morris declared war on the Delaware Indians, who, he claimed, had broken peace and

Without least provocation, and contrary to the most solemn Treaties, fallen upon this Province, and in most cruel, savage and perfidious manner killed and butchered great Numbers of the Inhabitants ... and laying waste the Country.

He then required "all His Majesty's Subjects of this Province" and invited "those of the neighbouring Provinces" to take every opportunity of "pursuing, taking, killing and destroying the said Delaware Indians, and all others confederated with them." To this end the Governor also offered monetary rewards for scalps and for live captured enemies. ${ }^{13}$

Governor Morris's declaration signals a breakdown in relations that up until then had been comparatively peaceful. One powerful element of the American foundation story is how William Penn established just and friendly relations with the first inhabitants of the region - in particular the Delaware Indians. In no other medium is the story better expressed than in Benjamin West's famous painting of the treaty at Shackamaxon between William Penn and the Lenapes. The image of this treaty has become an "icon of American history," in the words of Thomas Sugrue. ${ }^{14}$ It is easy to find celebrations of Penn's character and treatment of the Indians in earlier writings, such as those of the $19^{\text {th }}$-century Pennsylvania historian Peter Du Ponceau. He wrote of the "true merit" of William Penn which was to be found

in the honesty, the integrity, the strict justice with which he constantly treated the Aborigines of the land; in the fairness of all his dealings with them, in his faithful observance of his promises; in the ascendancy which he acquired over their untutored minds; in the feelings of gratitude with which his conduct and his character inspired them, and which they, through successive generations until their final disappearance from our soil, never could nor did forget, and to the last moment kept alive in their memories. ${ }^{15}$

13 The Pennsylvania Gazette, 4/15 1756 [CD-Rom Edition], American Philosophical Society, Philadelphia.

14 Thomas Sugrue, "The Peopling and Depeopling of Early Pennsylvania: Indians and Colonists, 1680-1720," The Pennsylvania Magazine of History and Biography, vol. CXVI, no. 1 (1992), 3.

15 Peter Du Ponceau, A Discourse on the Early History of Pennsylvania, Philadelphia: The American Philosophical Society, 1821. 
No one writes like this anymore, of course, but historian Thomas Sugrue concludes that the belief in friendly and civil relations as a consequence of Penn's character "is shared by virtually every historian writing about the colony's history. Few subjects evoke such consensus among historians as the history of early Pennsylvania."16 An American history text book from 1999 declares: "A pacifist with egalitarian principles, Penn attempted to treat Native Americans fairly. Before selling land to European settlers, he purchased it from the Delawares (or Lenapes)." ${ }^{17}$ Ethnohistorical and ecological approaches seem to have had little impact on the retelling of the encounter between William Penn's Quakers and Lenape Indians. ${ }^{18}$ Even in ethnohistorian James Merrell's sensitive analysis of the peoples in the Pennsylvania forests, which certainly deals squarely with the mythology surrounding the Shackamaxon treaty, there are shadows surrounding the realities of these contacts:

The Quaker province was a remarkably peaceable kingdom, a place unusual, even unique, in the annals of colonial British America .... The secret of that peace lay in a happy conjunction of Penn's benevolent views on Indians with the conditions his settlers found on their arrival. The nearby Delawares were predisposed to get along with the newcomers $\ldots$ these natives were inclined to be friendly. ${ }^{19}$

This predisposition or inclination towards friendliness does not receive further explanation. Thus even though Penn shares the glory with the Lenapes, the sentence structure makes it clear that the Indian disposition is a part of the general conditions which Penn and his settlers had to work with. I

16 Sugrue, "The Peopling and Depeopling," 4.

17 Mary Beth Norton, David M. Katzman, Paul D. Escott, et al., A People and a Nation. A History of the United States, $5^{\text {th }}$ ed. Boston and New York: Houghton Mifflin Company, 1999, 48.

18 See for example the otherwise acerbic Francis Jennings, who speaks highly of Penn and asserts the veracity of the treaty at Shackamaxon. Francis Jennings, The Ambiguous Iroquois Fmpire, New York and London: W. W. Norton and Company, 1984, 242-248. Or C. A. Weslager, The Delaware Indians, A History, New Brunswick: Rutgers University Press, 1991 [1972] who is quite severe in his descriptions of Swedish colonial leadership but has the following to say about William Penn: "The principle of goodwill and friendship toward all men lay at the very root of Quaker belief, and in this context it is not difficult to understand why Penn's treatment of the Indians differed from that of his predecessors. So much has been written about Penn's exemplary treatment of the Indians that it would appear little more remains to be said (156). As long as Penn lived, he held to the belief that Indians and whites could live together in harmony in his province if they were treated as equals, and during his lifetime the Indians had no complaints over land matters that were not resolved to their satisfaction" (165).

19 James H. Merrell, Into the American Woods. Negotiations on the Pennsylvania Frontier, New York \& London: W. W. Norton and company, 1999, 35. 
suggest that Europeans have been given far too much of the glory of that occurrence, and that even when Penn's Indian policy is questioned, he and his sons are still seen as the central actors of the plot.

Scholars have identified in the Seven Years War, raging between 1756-1763, a watershed in terms of violence, and in terms of creating "us" and "them" in the eastern woodlands. The horror of this war greatly consisted of the fact that people who had once lived as neighbors and known each other well, turned against one another and perpetrated the most terrible acts of cruelty. In the wake of this war Delaware Indians - once hailed as the "first to meet the English" - were othered and firmly placed outside the fold of the emerging nation. At this time it became significant to be able to distinguish between "domesticated" Indians, and "terrorist" enemies. A description of how the two groups might be identified focused on outward appearance: "The wild Indians generally go only [sic] a Shirt, whereas these [the friendly Indians] are always cloathed with something. A wild Indian is generally painted \& weareth a Feather, or some other Indian Ornament, these are never painted \& wear no feather, but they wear Hats or Caps. The wild Indians get their Heads shaved but these let the Hair grow naturally." 20 Consequently, while Penn occupied a central role as an embodiment of the foundational values of the new nation, his counterparts in this (fictive) meeting faded into not just oblivion but came to epitomize the dangers of the stranger - the murderous, barbarian terrorist. Historian Jane T. Merritt argues that

[t]he collective memory of white victims and the vivid imaginations of white settlers helped create an enemy that bore an uncanny resemblance to the Indian neighbors with whom they had recently interacted, and the image was most often Delaware. ... Demonizing Delawares became the first step in creating a racialized image of all Indians that could be exorcized only through all-out war. ${ }^{21}$

So these were the friendly Indians who Morris described as terrorists. While the friendliness and docility under the treaty elm have been much exaggerated, the same is true for the charges of unprecedented barbarity at mid-century. But the change does illustrate one dramatic and tragic period

20 Timothy Horsfield, n.d., "Characteristics of peaceable Indians," American Philosophical Society [Freeman guide \#960].

21 Jane T. Merritt, At the Crossroads. Indians \& Empires on a Mid-Atiantic Frontier, 1700-1763, Omohundro Institute of Early American History: The University of North Carolina Press, 2003, 191, 197. 
in the history of intercultural relations on the eastern seaboard, and one of pivotal importance for the subsequent experiences of white and red people in North America. The Delawares, who for a century had found peaceful means to deal with the changes they faced with colonization, took to violence after they had repeatedly been cheated out of land and influence. Morris's speech expressed another founding moment - that of exiling and redefining the colony's population in order to draw the line around "us." Examining the history of these pivotal events - both the foreplay and the aftermath - challenges both perceptions of agency and historical influence in the century before the US emerged as a nation, and the motivations for inclusion and exclusion in this nascent state.

\section{In the West - long before F. J. Turner}

Far, far away, in altogether another geographical region, but at roughly the same time, other encounters wove a complicated web of interaction that would impact the balance of power and perceptions for generations to come.

Comancher'a - the land of the Comanches and their allies the Wichitas-dominated international relations in the entire Texas, New Mexico, and northern Mexico region of America during almost a century. In fact, Pekka Hämäläinen has called the Comanche society a "shadow empire" and argues that they were in actuality the dominant colonial power in the region during the $18^{\text {th }}$ and early $19^{\text {th }}$ centuries. In contrast to many of the European colonial powers Comanches "did not form a rigid, centralised empire" as a consequence of their nomadic way of life. "Furthermore, they were reluctanct to join subordinate cultures to their own people or conquer vast areas. The Comanches were content with plundering, slaving, trading and extracting tribute." 22 This makes their domain less obvious to contemporary historians, attuned to certain definitions of empire.

"Texas," states Juliana Barr in her recent book, "thus does not fit any of the usual categories posited in colonial and Native American historiography. No stories of Indian assimilation, accommodation, resistance or 
perseverance here. Eighteenth-century Texas, instead, offers a story of Indian dominance." 23 This country then, contrary to popular images of Texas as the quintessential province of the US cowboy, offers perspectives that overthrow the master narrative of US Europeans on the offensive with Indians running for cover. Instead writes Barr, in Texas "not even a "middle ground' emerged." This "was not a world where a military and political standoff could lead to a 'search for accommodation and common meaning,' as drawn so persuasively by Richard White for the Great Lakes region. In Texas, native peoples could and did gain their ends by dominant force."24 Barr's book proceeds to demonstrate this dominance in everything from diplomacy to trade, war, slave raids, and intercultural and religious encounters. During the latter part of the $18^{\text {th }}$ century, for instance, the Comanches all but shut down both Spanish and Anglo provinces. In fact, still in the $19^{\text {th }}$ century of all the competing nations in Texas, "Comanches defended its territorial boundaries better than did Mexico and maintained its sovereignty longer than did the Texas Republic." ${ }^{25}$ Texas and Mexico thus offer a different template for encounters in North America, one that begs the question of the impermanence of the present. A teleological view of American (US) history as beginning with a handful of colonies on the east coast from which through a combination of war and disease native peoples were driven relentlessly westward in an inevitable process, is countered effectively by the events taking place as both Anglos and Spanish struggled for generations with how to best seek accommodation with Comanches. The present state and the present borders are just one point on a temporal scale, and there is little in history to help us predict what borders and configurations will develop in the near or distant future.

These two examples, Delawares on the East coast, and Comanches in the Southwest, demonstrate two different ways in which the chronology and the geography of the American US may be challenged.

23 Juliana Barr, Peace Came in the Form of a Woman, Chapel Hill: The University of North Carolina Press, 2007, 7; Richard White, The Middle Ground. Indians, Empires, and Republics in the Great Lakes, Cambridge: Cambridge University Press, 1991 (1995).

24 Ibid., 7.

25 Ibid., 234, 290. 


\section{Digging into the ground}

However, there are also other ways to explode the boundaries of the US. Trempealeau in western Wisconsin, on the banks of the Mississippi, is a small town that I encountered for the first time last year when I was asked to review a book by Laurie Hovell McMillin called Buried Indians. Digging Up the Past in a Midwestern Town. Unknown to me yet oddly familiar as McMillin describes family gatherings, life on the farm, the Lions' fundraiser, the Duck Pond and the water tower, children's games and high school antics. But this beguiling Midwestern charm began to unravel in the early 1990 s as the past literally emerged out of the ground. At that point archaeologists from the Mississippi Valley Archaeology Center and local residents clashed over plans to reconstruct and preserve near millenniumold Mississippian platform mounds found within the bounds of the town.

Trempealeau was settled primarily by northern or northwestern Europeans. It counts its origin back to French explorers in the $17^{\text {th }}$ century. One or two token Indians also appear in the town's geneaology, but local history telling places them firmly in the past. The landscape tells a different story. Trempealeau Mountain, effigy mounds, burial grounds, platform mounds, arrowheads - Indians are everywhere, yet conspicuously absent in the life of the town. The high school mascot is an Indian, but real Indians are rendered invisible. "Our heads were full of Hollywood Indians, and our hearts were full of local pride". as McMillin explains it. ${ }^{26}$ The author finds it difficult to get to meet and interview local Native people, and this illustrates just how wide the chasm is. Sometimes, however, interests converge for different reasons, as when the town fathers and Indian spokespersons both oppose the archaeological digs.

I am intrigued by how McMillin weaves together many threads or layers not to arrive at one truth, but at many. How complicated are the webs of relations in American soil, and how simplistically they are rendered when the bleached prairie grass layer of settlers is grafted onto its many other, and deeper, deposits! The stories are not new to students of Native American history. But McMillin refreshingly tells the story of her discovery of this past, uncovering, bit by bit, the many strata and diverging storylines and forces the reader to think differently about the landscape and the human impact upon it. 
What also becomes apparent through McMillin's telling of this story is that Indians, Ho-Chunks mostly, are still there, alive today yet all but invisible to other inhabitants of Trempealean. The inability to see their presence McMillin likens to a "benign face of violence." This benign violence, combined with a penchant for seeing oneself as "simple folks just trying to make a living" ensures that in Trempealean, as in so many other towns all over America, Indians past and present remain buricd and hidden.

\section{Expropriations}

Philip Deloria, historian and Lakota Indian, explored how white Americans have donned Indian attire in a variety of contexts from the Boston tea party up until the present and how these masquerades have changed form in the search for a distinctly American identity. Playing Indian (as his book is called) could fill different symbolic needs, such as emphasizing roots in an American, versus a European, origin, a connection to the natural environment of the continent, and a democratic yen for independence. But all of these identity games were possible only on condition that the real Indians were removed. ${ }^{27}$ Playing Indian has been an excellent tool for dealing with the contradictions inherent in US history and offered white Americans an opportunity to both keep the cake and eat it. In this imagery the Indians they played could be both civilized and indigenous; they could criticize modernity while simultaneously enjoying its fruit; they could indulge in a utopian and fanciful community project while holding on to fundamental American values. ${ }^{28}$ Deloria concludes that playing Indian

reflects one final paradox. The self-defining pairing of American truth with American freedom rests on the ability to wield power against Indians-social, military, economic, and political - while simultaneously drawing power from them. ${ }^{29}$

This paradox influences how history is told and how, when, and where Indians can be included. The values of national identity which Delo- 
ria explores is intimately tied to the history of national citizenship and Eric Foner emphasizes that "in a society resting, rhetorically at least, on the ideal of equality, the boundaries of the imagined community take on extreme significance ...The greater the substantive rights of American citizenship, the more important the boundaries of inclusion and exclusion." ${ }^{30}$

The Delawares and Comanches have not been chosen at random as examples for this talk. There are today over 300 federally recognized Indian nations covering the US. What I have said applies to the relationship between any of them and the US, but the historical experiences and agency of the Delawares and Comanches may well be thought of as indicator experiences. They indicate places in which the rifts in the borders tightly embracing the present US might be seen at their most obvious. They expose the necessity of a young nation to fix its limits, to determine its borders, and decide whom to include and exclude.

Where do we find the Delawares and Comanches today? That question may be answered in two ways - in history books, and in geography. I checked a number of prominent American History survey text books and found that they were mentioned only in two contexts, if at all. These surveys together cover about $17 \%$ of the market, and I have very little reason to suspect that the rest differ significantly from these. 


\begin{tabular}{|c|c|c|c|c|c|}
\hline Survey text & Colonial period & Early national & Post-civil war & $20^{\text {th }} \mathrm{c}$. & $\%$ \\
\hline $\begin{array}{l}\text { Who Built America? } \\
\text { Working people and the } \\
\text { Nation's Economy, Politics, } \\
\text { Culture, and Society (2000). }\end{array}$ & $\begin{array}{l}\text { 1740s/50s: Delaware } \\
\text { allegiances } \\
\text { Comanches raiding pueblos }\end{array}$ & $\begin{array}{l}\text { French traders providing } \\
\text { Comanches and Apaches } \\
\text { with horses }\end{array}$ & $\begin{array}{l}1860 \mathrm{~s} / 70 \text { s Comanches } \\
\text { pushed off "ancestral lands" } \\
\text { battles with "renegade } \\
\text { members" }\end{array}$ & - & $1,6 \%$ \\
\hline $\begin{array}{l}\text { The American Journey. } \\
\text { A History of the United States, } \\
(2002) \text {. }\end{array}$ & $\begin{array}{l}1750 \text { s "British emissaries } \\
\text { persuaded Delawares... to } \\
\text { abandon their French alliance" }\end{array}$ & $\begin{array}{l}1840 \mathrm{~s}-\text { force of federal army } \\
\text { ended Comanches long reign }\end{array}$ & $\begin{array}{l}1870 \text { s-Comanches subdued } \\
\text { on the souhern Plains }\end{array}$ & - & $3,9 \%$ \\
\hline $\begin{array}{l}\text { Enduring Vision. A History of } \\
\text { the American People, }(2000)\end{array}$ & $\begin{array}{l}\text { 1600s-Delaware contacts } \\
\text { with New Sweden, New } \\
\text { Netherland } \\
1730 \text { s-Delawares coerced } \\
\text { into selling land, forced under } \\
\text { Iroquois supervision; } 1740 \text { s- } \\
\text { disenchantment with British } \\
\text { 1780s prophet Neolin, } \\
\text { Delawares in war of independ- } \\
\text { ence, obliged to recognize } \\
\text { American sovereignty } \\
\text { Comanches moved onto high } \\
\text { plains with horses, by the end } \\
\text { of } 1700, \text { Spain made peace } \\
\text { with them. }\end{array}$ & . & $\begin{array}{l}\text { 1860s-1890s western Sioux, } \\
\text { Cheyennes, Arapahos, } \\
\text { Kiowas, and Comanches } \\
\text { faced US army in series of } \\
\text { final battles } \\
1868 \text { - Medicine Lodge } \\
\text { Creek Treaty }\end{array}$ & - & $3,5 \%$ \\
\hline $\begin{array}{l}\text { A People and a Nation. } \\
\text { A History of the United States, } \\
\text { (1999) } 5^{\text {th }} \text { brief edition. }\end{array}$ & $\begin{array}{l}\text { "A pacifist with egalitarian } \\
\text { principles, Penn attempted to } \\
\text { treat Native Americans fairly } \\
\text {...He also forbade the sale of } \\
\text { alcohol to Indians." } \\
\text { Settlers moving onto Delaware } \\
\text { land-Delaware refusal to } \\
\text { acknowledge American } \\
\text { sovereignty. }\end{array}$ & - & - & - & $3,5 \%$ \\
\hline
\end{tabular}




\begin{tabular}{|c|c|c|c|c|c|}
\hline Survey text & Colonial period & Early national & Post-civil war & $20^{\text {th }} \mathrm{c}$. & $\%$ \\
\hline $\begin{array}{l}\text { The American Experiment. } \\
\text { A History of the United States, } \\
(2002)\end{array}$ & $\begin{array}{l}\text { Prehistory } \\
\text { "As Quakers spread from the } \\
\text { coastline, relations with Indian } \\
\text { remained peaceful thanks to } \\
\text { the settler's religious convic- } \\
\text { tions about generosity and love, } \\
\text { and Penn's firm policy of } \\
\text { friendliness and pruchasing } \\
\text { titles for Indian lands." } \\
\\
\text { Raiding parties, epidemics, } \\
\text { Delaware fighting Americans. }\end{array}$ & $\begin{array}{l}\text { 1780s Apache and Comanche } \\
\text { years of fierce warfare } \\
\text { Delaware resettled in Indian } \\
\text { Territory, selling land in Kansas } \\
\text { Comanche encroaching on } \\
\text { resettled peoples, refusing to } \\
\text { settle }\end{array}$ & $\begin{array}{l}\text { Kiowa, Apache, and } \\
\text { Comanche "roamed the land } \\
\text { of present-day Texas and New } \\
\text { Mexico." } \\
\text { Medicine Lodge Treaty }\end{array}$ & - & $?$ \\
\hline $\begin{array}{l}\text { The Limits of Liberty. } \\
\text { American History 1607-1992 } \\
\text { (1995) }\end{array}$ & - & - & - & - & $?$ \\
\hline $\begin{array}{l}\text { America. } \\
\text { Past and Present (1987) }\end{array}$ & - & - & - & - & $3,4 \%$ \\
\hline $\begin{array}{l}\text { Howard Zin, A People's } \\
\text { History of the United States } \\
\text { (2001) }\end{array}$ & - & - & - & - & $1,2 \%$ \\
\hline
\end{tabular}


As can be seen the Delawares are discarded somewhere in the mid-eighteenth century - before the US had even become an independent country. By that time they had already served out their purpose as Penn's guileless foils. Comanches are excluded as actors in the story about how the US became a nation when the origins of this nation is sought in a few colonies on the east coast who then proceeded to expand westward and incrementally subsume more and more territory into the "us." ${ }^{31}$ Westward expansion thus became the engine that propelled the entire nation forwards in time and space. No wonder it is so difficult to fit Indians into this story. Their presence, their actual presence today and their present and past territorial claims, threaten the foundation of the US like no other population, in a way which no immigrant group could ever do.

Geographically Delawares and Comanches are both found living as neighbors in present-day Oklahoma. And Oklahoma 2007 may be a very good test case for the arguments presented here. The state celebrates its $100^{\text {th }}$ anniversary as a US state. I have attempted to track the state's centennial celebrations, and I have asked a number of Native Americans in the state what they think about these commemorations. Notably absent from any of the official centennial sites on the web are references to the Dawes Act (passed in 1887) and forced allotment of Native land, which was extremely important for Oklahoma's Native population as it led to the almost total loss of control over land, especially in the western part of the state. The responses I received supported this observation. Indian interest in the commemorations has been mixed-few outright protests as against the celebrations of Columbus in 1992, but also very little participation. One person commented: "There are some Indians involved but it appears to be 'cosmetic'."'32 In an article in the Tulsa World Osage Principal Chief Jim Gray noted that "[t]he cost of statehood had a huge price for Indians." It was also in this article that I found a Comanche commentary on the events. Wallace Coffey, who is chairman of the Comanche Nation, stated that his people will not celebrate the state's centennial: "Look at what we got out of it ... You can't spoon-feed people your culture when your true history is omitted from the history books." ${ }^{33}$

310ther conceptual frameworks are possible, as demonstrated for example by Arrell M. Gibson's attempt to view American history from the Pacific rim. A. M. Gibson (with the assistance of John Whitehead), Yankees in Paradise: The Pacific Basin Frontier, Albuquerque: University of New Mexico Press, 1993.

32 Email communication from Vanessa Jennings, 5/25 2007.

33 S.E. Ruckman, "Centennial not a time of joy for all," Tulsa World 11/13/2006. 
The Oklahoma festivities are an example of the United States' exuberant penchant for celebration matched only by its short memory. Or as Michael Kammen expresses it: "the American inclination to depoliticize the past in order to minimize memories (and causes) of conflict." 34 We as "others" express more fully what is inclusion and exclusion. We who are concerned with American Studies from the outside of the US should not let that inclination inhibit us from joyfully skipping over boundaries of exclusion in time as well as space!

I therefore propose that the first sentence of the purpose of the Nordic Association for American Studies should read

to encourage all study related to America as a concept and geographical space, particularly in Denmark, Finland, Norway, and Sweden. 